\title{
Changes of the Intracellular Reducing Intensity in the Pollen Mother Cells During Meiosis of the Young Lilium Anthers ${ }^{1}$
}

\author{
Mamoru lijima \\ The Botanical Institute of the Keio University
}

Received January 8, 1953

\section{Introduction}

In our previous paper (Shinke, Iijima and Hiraoka 1947), it was assumed that the "reducing intensity" increased in the sporogenous tissue from premeiosis to meiosis. Strictly speaking, however, with the histochemical method used in that paper, it has only proved that certain substances were contained both in the sporogenous cells and in the pollen mother cells, which had reduced the reagents used.

Further studies are necessary, therefore, to examine the "total reducing intensity" in the sporogenous tissues and to determine exactly the important problem whether the "total reducing intensity" really increases or not in the sporogeneous cells after the division has entered into meiosis. Such determination seems to be of great significance as it must indicate one of the most remarkable physiological characters of meiosis, which are quite unwellknown in the present time.

In the present paper the results obtained by the indicator method using several dyes, being available as $\mathrm{rH}$ indicators, are reported. Among these dyes, N.V.E. Grübler has especially proved as the most fittest in the comparative studies of the reducing intensity between the sporogenous and pollen mother cells.

\section{Material and method}

As material young anthers of Lilium speciosum in different stages during their development, from ca. $2 \mathrm{~mm}$ to $15 \mathrm{~mm}$ in length, were used. Lilium philipiensis and Tulipa sp. were also used. As any remarkable difference was not found among them, in this paper only the results obtained with Lilium speciosum are stated. In the determination of the total reducing intensity of the cells, the following dyes were used: Neutral Violet Extra (N. V.E.) Grübler was used as the most suitable; other dyes such as Neutral Red, Nile Blue, Janus Green and others were also tried to use, but they gave no clear result.

1. Preliminary note to "Studies of mitosis and meiosis in comparison. IX." Original work described here in this article was carried out while the writer was in the Kyoto University.

2 Confer Seifritz 1936. Protoplasm. 
Methylene Blue, Toluidine Blue were found as suitable, yet they gave frequently confusing results; the observation was often disturbed by the existence of certain yellow pigments, which were existed in the sporogenous and in the pollen mother cells.

With N.V.E., two different dilute solutions were used; $(1: 1000)$ and (1:2000) solutions were prepared using di-destilled water according to Stow (1933), and in this investigation the latter concentration was mainly used. The sections were obtained transversely by the hand-sectioning and they were immersed in the solution about 30 minutes and then observed under the microscope with various magnifications. With other dyes the same method was also used, but in these cases the solution was the concentration of $(1: 1000)$ and the time of immersion was about 30 minutes.

\section{Preliminary experiment}

N. V. E. Grübler is composed of two independent dyes: New Blue and Neutral Red are mixed in $(1: 2)$ ratio. With this dye, we made three kinds of experiments on the points as will be described as follows: the change of colours in various solutions, which prepared as to show variously oxidised or reduced conditions by certain suitable reagents; the change of colours in various $\mathrm{pH}$ solutions; the change of colours and its redoxpotentials being measured by using Michaelis' vessel.

In the first experiment the change of the colours was examined in vitro, which occured when various oxidizing and reducing reagents were added to the dye solution. As the oxidizing agent we used $\mathrm{H}_{2} \mathrm{O}_{2}, \mathrm{KCLO}_{3}$, ferricyanatum, and in reducing the solution, $\mathrm{Na}_{2} \mathrm{~S}_{2} \mathrm{O}_{3}$ was used. The results coincide with the table used by Stow (1933) as shown in Table 1 with only slight difference.

Table 1. The colours of N.V.E. solutions in variously oxidated and reduced conditions

\begin{tabular}{|c|c|c|c|c|c|c|c|}
\hline \multirow{3}{*}{$\begin{array}{l}\text { Conditions } \\
\text { in ec. }\end{array}$} & \multirow{2}{*}{\multicolumn{3}{|c|}{$\begin{array}{l}\text { Reduced conditions } \\
\mathrm{N}_{2} \mathrm{~S}_{2} \mathrm{O}_{3}(1 / 100 \mathrm{~mol} .)\end{array}$}} & \multirow{3}{*}{ Untreated } & \multirow{2}{*}{\multicolumn{3}{|c|}{$\begin{array}{l}\text { Oxidized conditions } \\
\mathrm{H}_{2} \mathrm{O}_{2} \text { (ca. } 1 / 100 \mathrm{~mol} \text { ) }\end{array}$}} \\
\hline & & & & & & & \\
\hline & $0.17-0.35$ & $0.1-0.15$ & 0.035 & & 0.035 & $0.07-0.1$ & $0.17-0.35$ \\
\hline Colours & \multicolumn{2}{|c|}{ Carmine red } & $\begin{array}{l}\text { Coral- } \\
\text { pink }\end{array}$ & $\begin{array}{l}\text { Mulberry } \\
\text { purple }\end{array}$ & \multicolumn{2}{|c|}{ Amethyst violet } & $\begin{array}{l}\text { Dark } \\
\text { bluish } \\
\text { violet }\end{array}$ \\
\hline
\end{tabular}

Secondly the change of tints in various $\mathrm{pH}$ solutions was observed. The McIlvaine's buffer was used. Between $\mathrm{pH} 4$ and $\mathrm{pH} 7$ in vitro hardly a slight variation is known in the tints with the dye solutions. The results are summarized in Table 2.

Thirdly the redox-potential was measured by using the Michaelis' vessel under $\mathrm{N}_{2}$-gas ; in titration, $\mathrm{Na}_{2} \mathrm{~S}_{2} \mathrm{O}_{3}$ was used as the reducing agent in $(1: 100)$ or $(1: 1000)$ molar solutions. In the back titration we used 
Table 2. The colours of N.V.E. solutions in various $p H$

\begin{tabular}{c|c}
\hline $\mathrm{pH}$ & Colours \\
\hline 4.0 & Mulberry purple \\
\hline 5.0 & Mulberry purple \\
\hline 6.0 & Mulberry purple \\
\hline 7.0 & Mulberry purple \\
\hline 8.0 & Strawberry pink \\
\hline
\end{tabular}

\begin{tabular}{c|c}
\hline $\mathrm{pH}$ & Colours \\
\hline 7.4 & Begonia rose \\
\hline 7.8 & Eosin pink \\
\hline 8.0 & Strawberry pink
\end{tabular}

2-6-dichlor-phenol-indophenol and ferricyanatum in the same concentration as sodiumthiosulphate. One example of the titration curve is shown in Fig. 1. The $\mathrm{E}^{\circ}$ of this solution stands at $320 \mathrm{mv}$, where the tint of the solution changes from Searet into Capcine Yellow (perhaps the $\mathrm{E}^{\mathrm{o}}$ of Neutral Red). The change of colours ${ }^{1}$ of the dye are also summarized in Fig. 1 showing the corresponding millivolts.

In this back titration it was noticed that the solution became Scaret at near $-220 \mathrm{mv}$., while some greenish fluorescence always remained in the solution. Recently Lewis (1935) has reported on a dye, which has been named as "Fluorescent X". This dye is said to have been produced by reducing Newtral Red with sodiumthiosulphate in the phosphate buffers. It seems to be highly possible that the "Florescent $X$ " may coincide with the fluorescence substance in N.V.E. in this experiment, which was produced under the same conditions, though in the latter case New Blue is mixed in the solution.

Another most remarkable fact is that the colour of the solution changes under $\mathrm{N}_{\text {.. }}$-gas from Mulberry purple into Carmine without the titration of any reducing reagent. At the same time, the redoxpotential of the solution falls gradually as shown in Table 3 . This phenomenon is interpreted as showing the easy reduction of New Blue, even before the titration.:

Thus N.V.E. is a very interesting dye, which changes its tint from Mulberry purple into Carmine even by the displacement of air with $\mathrm{N}_{2}$-gas. The latter fact may

Table 3. Falls of redoxpotentials within N.V.E. solutions by the displacement of air with No-gas

\begin{tabular}{r|c|c}
\hline $\begin{array}{r}\text { Time in } \\
\text { minutes }\end{array}$ & $\begin{array}{c}\text { Eh in } \\
\text { millivolts }\end{array}$ & Tints of solutions \\
\hline Air $5^{\prime}$ & 229 & Grape violet \\
$15^{\prime}$ & 227 & \\
$20^{\prime}$ & 220 & \\
\hline $\mathrm{H}_{2} 30^{\prime}$ & 173 & Red violet \\
$35^{\prime}$ & 142 & \\
$40^{\prime}$ & 126 & \\
$50^{\prime}$ & 109 & \\
$60^{\prime}$ & 080 & \\
$80^{\prime}$ & 051 & Violet red \\
$100^{\prime}$ & 025 & \\
$120^{\prime}$ & 018 & Red with some \\
& & violet portions \\
\end{tabular}
be the reason why this dye was

1 Colour Index.

Both these changes here mentioned are reversible. 
suitable for the present investigation; as it seems to have the ability to show very delicate difference in Eh by its colour change.

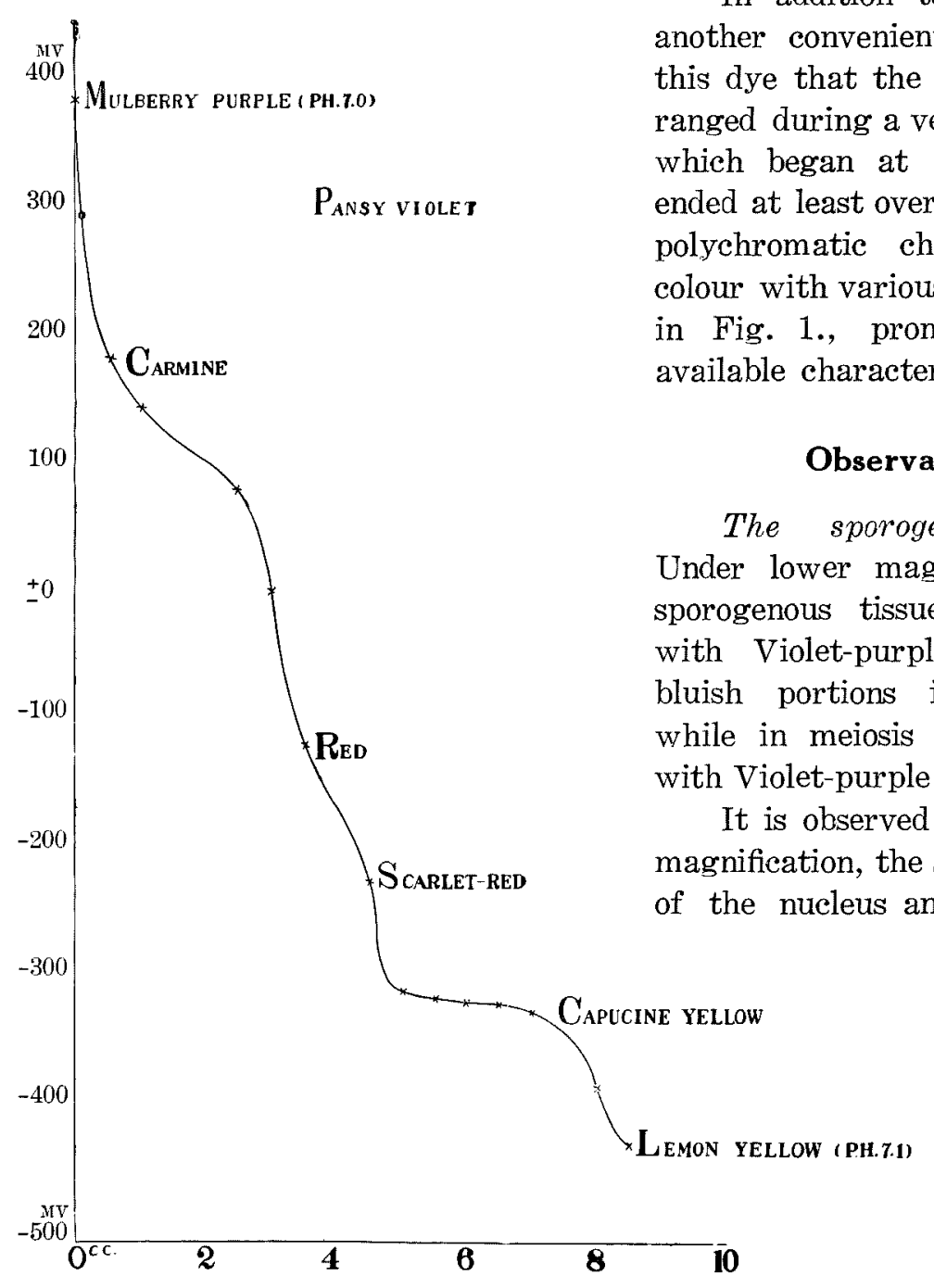

Fig. 1. Explanation in text.

In addition to this, it was another convenient character of this dye that the Eh of N.V.E. ranged during a very wide scale, which began at $-320 \mathrm{mv}$. and ended at least over $400 \mathrm{mv}$. The polychromatic changes of the colour with various Eh, as shown in Fig. 1., promised fruther available character of this dye.

\section{Observation}

Under lower magnification, the sporogenous tissue is coloured ${ }^{1}$ with Violet-purple with much bluish portions in premeiosis, while in meiosis it is coloured on, the staining colour plasm change with the proceeding of the division, especially when they entered into meiosis. Namely as follows : at the beginning of premeiosis, both the cytoplasm and the nucleus are coloured with Violetpurple with some bluish portions indicating that the "reducing intensity" of the cell-complexes is relatively weak in these stages.

At the differentiation stage of premeiosis where the tapetal tissue has become already distinguishable from the sporogenours tissue, the cytoplasm is stained with the same colour as in the previous stage, while the nucleus is of ten stained with Pancy-violet.

1 "coloured" is used in the present paper meaning the "diffuse" staining. 
At the last premeiotic interphase or near that stage, the cytoplasm is stained in Violet-purple. The bluish portion has almost disappeared at this stage, indicating a slight increase of the "reducing intensity". The nucleus is stained in dark Violet with some purple portions. In the prophase of the first division of meiosis, the cytoplasm is stained in Rose colour with few purple portions indicating some increase of the "reducing intensity" in this stage. The nucleus is stained in Purple. In the more later stages of meiosis, concluding the second division, the cytoplasm is stained in Rose colour with much purple portions showing slight decrease of the "reducing intensity" of the cell-complexes again. The nucleus is stained in Purple. But the degree of the "reducing intensity" seems to be weaker than the sprongenous cells because any bluish colour has never been clearly perceptible in this case.

The minute granules in the cytoplasm, which have been announced to show many special activities to various histochemical reactions (Shinke, Iijima and Hiraoka 1947), were turned much attention also in the present investigation. Generally speaking, these granules are not stained.

It was noticed in the pollen mother cells, which were in the pachrtene stage, that certain large granules, were stained particularly in Red, while the others were remained unstained. This reddish staining of the granules seems to be attributed to some physiological condition of the cell-complexes; first as the Brownian movement had been particularly ceased in these granules; secondly as it was observed that in the wounded cells the minute granules become well stained in Red. In this case, just mentioned above, the staining phenomenon in certain granules is interpreted as the first indication of the wounding or some validity of the cell function at least.

The nucleoli are stained through all these stages in Violet with N. V. E., such particularity in the staining colour of the nucleoli is especially clear when the cells are stained with Toluidine Blue, where the nucleoli are coloured with Violet while other components of the nucleus are bluish stained.

The tapetal tissue: As summarized in the Table 4, the staining colour of the cytoplasm changes from Violet-purple or Purple into Eosin pink with some purple portions as the sporogenous cells enter into meiosis. This change of the staining colour is interpreted as to show some increase of "reducing intensity" of the tapetal cells when they enter in the meiotic division. It is here to be noted, however, that the degree of the inerease in the reducing power during the development of the pollen mother cells are more or less lower than in the sporogenous cells in this tissue.

Another notable fact is that in the tapetal cells any change is not found in the staining colour in the second meiotic division stages; this fact indicates that there is not any decrease of the "reducing intensity" in tapetum. These two facts are the main difference between the sporogeneous tissue 
and the tapetal tissue.

The parenchymatic tissue: In this tissue any particular change is not observable during the development of the pollen mother cells. While other cell components did not show any particular staining colour, the nucleus is stained in Pink with some violet portions diffusely.

The nucleoli, in most cases two in number, are stained in Red. This staining colour is different somewhat from the case in the sporogenous and tapetal tissues. In the latter two cases, the nucleoli are stained in Violet as described in the preceeding pages.

The epidermis: Both in premeiosis and meiosis, the epidermal cell is stained in Rose colour often with some reddish portions. The large vacuole in the cytoplasm is also stained in Rose as other cell-components.

These changes in the staining colours of the various tissues in the Lilium anthers during the development of the pollen mother cells, are summarized in Table 4.

Observation with Methylene Blue

Sporogenous tissue: In the earlier stages of premeiosis, both the cytoplasm and the nucleus are stained bluish.

Near the last premeiotic interphase, the cytoplasm is stained in greenish Blue, sometimes the nucleus is stained in Light methylene blue.

In the prophase of the first division of meiosis, the cytoplasm is stained in Light methylene blue or in greenish Blue frequently.

The tapetal and other tissues: In premeiosis, the tapetum and other tissues and the part around the vascular bundles, are stained all in Methylene blue.

In meiosis, the tapetal tissue often appeared more deeply Blue under lower magnification. However, the observation under higher magnification revealed that this appearance was caused by some pathological nuclear staining. The cytoplasm shows more or less light greenish colour throughout meiosis.

Results with Methylene Blue and others: There is no difference between the results with M.B. and T.B., here the results with the former are only shortly described. They are quite in accordance with the result obtained with N.V.E. Namely it is here also perceptible as in the case with N.V.E., that the "reducing intensity" increases within the sporogenous and tapetal cells as they enter into the meiotic division and again slightly decreases only in the sporogenous tissue near the end of meiosis.

\section{Conclusion}

Now we may speak the outline of history of the "reducing intensity" in the sporogenous tissue from the results, on which we have just described

1 Further precise and generarized studies are to be published later by the writer with the tapetal and the transitory layers. 
above : the results are arranged in Table 4. Such difference in the staining colours between the sporogenous cells and the pollen mother cells are interpreted as showing first the increase of the "total reduceing intensity"

Table 4. Changes of the staining colours in the sporogenous and the pollen mother cells with N.V.E.

\begin{tabular}{|c|c|c|c|c|}
\hline \multirow{2}{*}{$\begin{array}{cc} & \text { Tissues } \\
\text { Stages } & \end{array}$} & \multicolumn{2}{|c|}{ Sporogenous tissue } & \multicolumn{2}{|c|}{ Tapetal tissue } \\
\hline & Nucleus & Cytoplasm & Nucleus & Cytoplasm \\
\hline $\begin{array}{l}\text { Premeiosis } \\
\quad \text { Undifferentiation } 1\end{array}$ & $\begin{array}{l}\text { Violet purple } \\
\text { with some } \\
\text { bluish portions }\end{array}$ & $\begin{array}{l}\text { Violet purple } \\
\text { with some } \\
\text { bluish portions }\end{array}$ & & \\
\hline Differentiation & $\begin{array}{l}\text { Dark Violet } \\
\text { with much } \\
\text { purple portions }\end{array}$ & Violet purple & $\begin{array}{l}\text { Violet purple } \\
\text { with some } \\
\text { bluish portions }\end{array}$ & $\begin{array}{l}\text { Violet purple } \\
\text { with much } \\
\text { bluish portions }\end{array}$ \\
\hline $\begin{array}{l}\text { The last premeiotic } \\
\text { interphase }\end{array}$ & Purpie & $\begin{array}{l}\text { Rose colour } \\
\text { with few } \\
\text { purple portions }\end{array}$ & Purple & Purple \\
\hline $\begin{array}{l}\text { Meiosis } \\
\text { 1-prophase in } \\
\text { 1st division }\end{array}$ & Purple & $\begin{array}{l}\text { Rose colour } \\
\text { with some } \\
\text { purple portions }\end{array}$ & Deep Rose pink & $\begin{array}{l}\text { Deep Eosin pink } \\
\text { with some } \\
\text { purple portion }\end{array}$ \\
\hline $\begin{array}{l}\text { 1-metaphase to } \\
\text { interkinesis }\end{array}$ & Violet purple & Violet purple & Deep Rose pink & $\begin{array}{l}\text { Deep Eosin pink } \\
\text { with some } \\
\text { purple portions }\end{array}$ \\
\hline 2nd division & & & $\begin{array}{l}\text { Deep Rose pink } \\
\text { with some } \\
\text { purple portions }\end{array}$ & $\begin{array}{l}\text { Deep Eosin pink } \\
\text { with some } \\
\text { purple portions }\end{array}$ \\
\hline
\end{tabular}

of the pollen mother cells in the first division, secondly showing its slight decrease in the second division. This result is based on the staining colour of the cytoplasm. With regard to the staining colour of the nucleus, there are conflicting theories on this subject, but the writer is inclined to the view that these staining phenomena of the nucleus may be contributed to certain other conditions, which have no bearing on the "reducing intensity". Further the nucleus was observed occasionally to be only stained with certain dyes.

As it is well known that Eh of a dye changes with its medium $\mathrm{pH}$, the determination of $\mathrm{pH}$ becomes necessary before we get a conclusion about the "reducing intensity" or $\mathrm{rH}$ in the indicator method.

The $\mathrm{pH}$ of both the sporogenous and the pollen mother cells of Lilium philipiensis was determined by using the Range Indicator Method. With Bromcresyl Green (B. C. G.) both cells are stained in bluish green showing the $\mathrm{pH}$ range between 4.6 and 5.0. Ariy remarkable difference is not perceptible between the sprogenous and the pollen mother cells. The result of the present investigation confirms the observation of Yamaha (1932, 1935), but the range of $\mathrm{pH}$ determination is roughly reported here."

\footnotetext{
1 In this stage, any difference is not remarkable between tapetal and sporogenous tissue, i.e., they are not yet differentiated morphologically. While another method reveals them physiologically.

2 To be published later more precisely in the studies of tapetum by the writer.
} 
Shortly speaking, from the results of the above observation, it is now at least clear that $\mathrm{pH}$ in both cells does not show any remarkable difference. The changes of the staining colour by the dyes, such as N.V.E. and others between both cells, are therefore not caused at least only by $\mathrm{pH}$ difference (confer Table 2).

Now it becomes highly probable that they show the difference of the "reducing intensity" of the cell complexes between the sporogenous cells and the pollen mother cells.

The staining colour of the cytoplasm with N. V.E. indicates that the redox-potential of the sporogeneous cells, which are in the premeiotic division, is to be at least over $400 \mathrm{mv}$. (350 mv. at $\mathrm{pH} 5.0)$, while the potential falls in the first prophase till near $200 \mathrm{mv}$. to $100 \mathrm{mv}$. and the potential shows again a slight increase in the later stages in meiosis.

This result is also proved to be in accordance with the results obtained by other dyes such as Methylene Blue, Toluidine Blue and others. From observations with these $\mathrm{rH}$ indicators, we come to the following result: in meiosis the Eh of the pollen mother cell is slightly under the $\mathrm{E}^{\circ}$ of both Methylene Blue and Toluidine Blue, which stands both at $100 \mathrm{mv}$. at $\mathrm{pH} 5.0$, and far above the $\mathrm{E}^{\circ}$ of Nile Blue, which lies at -20 mv. at $\mathrm{pH} 5.0$.

Combining these two results, we come to the following conclusion: the sporogenous cells are assumed to have a redox-potential over $350 \mathrm{mv}$. ( $\mathrm{pH} 5.0$ ), while the pollen mother cells are to be $-20 \mathrm{mv}$. to $110 \mathrm{mv}$. ( $\mathrm{pH} \mathrm{5.0)}$.

By use of the more suitable dyes, such as Cresylblue, Cresylindophenol and others, we might have gained more precise value. Further opportunity is waited for these supplimentary experiments.

It was found by the later studies of the writer that such difference between premeiosis and meiosis is a general phenomenon ${ }^{1}$ with many vascular plants with few exceptions. It seems that these exceptional cases to have some connection" with the bulb plants and some unknown substance.

In shor $t$, we come to the tentative conclusion as follows: the "reducing intensity" of the sporogenous cell-complexes, or if not that, then at least the relative rate of the oxidation and reduction on the cell-complexes, is more stronger in the pollen mother cells than in the sporogenous cells. Such phenomenon is limited to the sporogenous tissue and seems to show one of the physiological character of "meiosis". The tapetum tissue, which has the same origin with the sporogenous tissue, shows an intermediate form between the sporogenous and somatic tissues.

The immersion method used in the present study has certain failing point, especially when the $r \mathrm{H}$ indicators are used. The thickness of the sections, the quantity of the dyes entering in the cells, are not quite equal in a strict sense. The microinjection method is more suitable in such point, but in N.V.E. certain points are less to be attached.

1. To be published later by the writer.

To be published later by the writer. With seasonal substance it will be published later by Shinke, Shigenaga and Iijima. 
Further precise studies on the electrical messing on the redox-potentials with the sporogenous and other tissues of Lilium anthers and others, are now under preparation.

The writer wishes to acknowledge his indebtness to Emer. Prof. Kuwada and Prof. Shinke of the Kyoto University under whose kindness and encouragement the present investigation was done, and to Prof. Kubo of the Medical Faculty of the Osaka University, the writer is also indebted as much valuable technical advicement.

\section{Summary}

1. The total reducing power in various tissues of Lilium anthers, especially of the sporogenous tissue (the sporogenous and the pollen mother cells), was determined by means of the indicator method during the development of the sporogenous tissue.

2. The reducing power of the sporogenous and tapetal tissues increases from premeiosis to meiosis remarkably, while in other tissues no such remarkable increase is seen.

3. The redox-potentials of N.V.E. Grübler were determined by using Michaelis' vessel with the changes of its colours.

\section{Literature cited}

Lewis, M. R. 1935. Experimental American association of anatomist.

Sinke, N., Iijima, M. and Hiraoka, T. 1947. A histochemical study of Lilium anthers. Mem. Coll. Sci. Kyoto Univ. 19.

Stow, I. 1933. On the female tendencies of the embryosac-like giant pollen grain of Hyacinthus orientalis. Cytologia 5.

Yamaha, G. 1935. Ùber die pH-Schwankung in der sich teilenden Pollenmutterzelle einiger Pflanzen. Cytologia 6. 